\title{
TURKISH-SOMALI RELATIONS: CHANGING STATE IDENTITY AND FOREIGN POLICY
}

\author{
Dr. Abdurrahim Siradag \\ King Fahd University of Petroleum and Minerals
}

\begin{abstract}
This article will examine the driving dynamics behind the increasing relations between Turkey and Somalia. Turkey has been an important actor on the African politics since the AK Party (Justice and Development Party) came to power in 2002. For instance, while Turkey only had 12 embassies across the continent until 2005, it currently has 35 . Turkey is today among the countries in the world having one of the most diplomatic missions on the African continent. Turkey's economic relations with the continent have also changed significantly. Whereas Turkey's total trade with Africa was 2 billion dollars in 2005, it is presently about 22 billion dollars. Importantly, Turkey is aiming to increase her total trade with Africa up to 50 billion dollars until 2020. Furthermore, Turkish NGOs are actively involved in many humanitarian projects in the different African countries. Turkey has particularly paid a great deal of attention to increasing political, economic and social relations with Somalia during the AK Party government. This article argues that the AK Party has been establishing a new foreign policy identity and transforming the parameters of the traditional Turkish foreign policy through the social interactions with Somalia.
\end{abstract}

Keywords: AK Party, Turkey, Somalia, Africa, Foreign Policy, Politics, Economics, History.

\section{INTRODUCTION}

Since then the Prime Minister Recep Tayyip Erdogan -the current President of Turkey- visited Somalia on 19 August 2011 with a large delegation including his family members, politicians, artists, singers, the four ministers, the president of the Religious Affairs of Turkey, and businessmen in order to draw attention of the world to the severe droughts that occurred in East Africa in 2011 ("Basbakan Somali'de", 2015) Turkey has actively developed her relations with this country in a wide range of fields. Even though the UN warned of the danger of the visiting of Somalia due to the ongoing civil war in the country, the President Erdogan has become the first statesman who visited the war-torn country since 1990 apart from Africa. Turkey also became the first country among the European and Asian 
countries appointing her ambassador in Somalia in 2011 and establishing the first diplomatic relationship with the country (Sanei, 2013).

While many European countries carry out their diplomatic missions within Nairobi, Kenya for Somalia due to the security reasons, Turkey opened her embassy in the capital of Mogadishu. The President Erdogan has paid his second official visit to Somalia on 25 January 2015 despite a terrorist bombing in Mogadishu on 22 January 2015. After Turkey's active involvement in Somalia in 2011, the international actors have begun to establish their diplomatic relations with Somalia, including the US, Britain, and China. Ali emphasizes that the Erdogan's visit made a bandwagon effect in the world for Somalia (Ali, 2011). According to Sanei, Turkey opened the door of Somalia to the world (Sanei, 2013). The Somali Prime Minister highlighted that "Turkey's visible presence on the ground ended the isolation of Somalia and the stigma of the country being designated as a no-go zone" (International Crisis Group, 2012, pg.6). It can be said that Somalia has been the most important example for Turkey to deepen and expand Turkish foreign policy towards Africa.

This research highlights that the AK Party have been particularly establishing a special relationship with Somalia due to the fact that the AK Party has aimed to change the principles of the Kemalist/traditional foreign policy. Turkish-Somalia relations indicate that Turkey has set up a new foreign policy identity despite. Bingol claims that there are three important factors behind the Turkey's growing involvement in Somalia. 1. The Islamic values the Turkish politicians embrace, 2. To open the new markets for the Turkish businessmen, and 3. To strengthen a geo-strategic advantage in world politics (Bingol, 2013). According to Akpinar, there are five important purposes of Turkish foreign policy towards Somalia. First was to end Somali's international isolation. Second was the provision of inclusive humanitarian aid. Third was the maintenance of security in the security. Fourth was the reconstruction of the infrastructure. Fifth was the strengthening of the unity and solidarity among the Somali nations (Akpinar, 2013).

The main questions this research will answer are how the AK Party has changed her traditional foreign policy identity? And why the AK Party has particularly strengthened her relations with Somalia? What are the main motivations behind the Turkey's active involvement in Somalia?

\section{THE HISTORICAL TIES BETWEEN TURKEYAND SOMALI}

The Ottoman State not only had deep political, economic, social and military ties with North Africa but also she had strong relations with 
East Africa tracing back to the $16^{\text {th }}$ century. East Africa was strategically important place for the Ottoman State in terms of the protection of the Holy Places and the sea and trade routes in this region. Historically, Eritrea, Djibouti, Somalia, Sudan, and Ethiopia were partially or entirely part of the Ottoman State. Particularly, the Ottoman State had a good relationship with the Muslim Sultanates in the region including the Sultanates of Harar and Zanzibar. During the $16^{\text {th }}$ century, the Sultanate of Harar was an important power in East Africa which controlled over Eritrea, Djibouti, Somalia and Ethiopia. The Ottoman provided political, economic, social and military support for the Muslim Sultanates to strengthen them and to prevent the colonial policy of Portugal in East Africa (Ugur, 2005).

The relations between the Ottoman State and East Africa began to weaken after the secular Republic of Turkey was established in 1923. The secular Turkey mainly focused on the domestic issues in the beginning years rather than deepening and expanding historical relations with East Africa. Turkey always maintained her relations with the countries in East Africa at the lowest level until 2000. Turkey's secular identity was the main reason to decrease historical relations with East Africa. In 1984, Turkey donated 10 million dollars for the countries in East Africa through the Organization of the Islamic Cooperation (OIC) to fight against the severe droughts that occurred in this region in 1984 (Erol \& Altın, 2012). Turkey opened her first diplomatic mission in East Africa in Ethiopia in 1926. While Somalia opened her diplomatic mission in Ankara in 1976, Turkey opened her first diplomatic mission in Mogadishu in 1979. Turkey's diplomatic mission in Somalia served in the country until the civil war began in Somalia in 1991. Meanwhile, Turkish commander Cevik Bir commanded the United Nations Somalia Mission (UNOSOM II) between 1993 and 1994 in order to sustain peace and security in the country. However, the role of UNOSOM II in Somalia was so limited, and therefore failed to establish long-standing peace and security in the country. On the contrary, political and security developments in Somalia got worst after the UNOSOM II ("The UN Failures", 2015).

The geopolitical changes on the international system forced Turkey to redefine her foreign policy after the Cold War era. After the collapse of the Soviet Union, Turkey accepted a multi-dimensional foreign policy. Turkey prepared a strategy towards Africa in 1998 to increase relations with Africa entitled as "Africa Action Plan". According to this strategy, Turkey will focus on strengthening political, economic, social and cultural relations with Africa at the highest level. Even though the strategy was a significant step to launch a new foreign policy towards 
Africa, it could not be implemented by the Turkish governments successfully. Because the Turkish government consisted of weak coalition parties and the government did not have enough financial power to carry on it (Siradag, 2013).

Turkey paid a great deal of attention to Somalia as of 2011. The relations between Turkey and Somalia have showed that Turkey has developed a long-term strategy towards Somalia rather than shortterm policy. Somalia has been a significant example for Turkish foreign policy to implement a new foreign policy initiative. Particularly, Turkey has carried out a multidimensional approach to build up peace, security and stability in Somalia. It can be said that the case of Somalia has demonstrated that Turkey has changed her static foreign policy and accepted a proactive foreign policy.

\section{POLITICAL AND DIPLOMATIC ENGAGEMENTS}

The AK Party government has taken significant steps to increase political and diplomatic relations with Somalia in line with the Africa Action Plan of 1998. The high-level visits between the countries, the opening of the new embassy, working together with international organizations on Somalia and the establishment of friendship group between the parliaments have all increase political rapprochement with Somalia. On the other hand, the components of political and diplomatic relations between Turkey and Somalia have been extended significantly over the years. The humanitarian assistance programme is the first and has been one of the most important components of it. The second aspect is related to increasing the capacity of state-building of Somalia and the last one is linked to Somalia's economic development.

The first official contact between Turkey and Somali began when the then Turkish Prime Minister Erdogan attended the African Union (AU) Summit in Addis Ababa on 29-30 January 2007. Erdogan met the late President Abdullah Yusuf Ahmed at the summit and Erdogan requested from him to submit a proposal to Ankara related to Somali's issues $2016 / 2$ and needs. In this regard, the former Transitional Federal Government (TFG) President Sharif Sheikh Ahmed made three visits to Turkey before Erdogan paid his first official visit to Somalia in August 2011 (International Crisis Group, 2012). Erdogan's historic visit to Somalia in August in 2011 became a milestone in establishing political and diplomatic relations with Somalia. After this historic visit, Turkey re-opened her embassy in Mogadishu on 1 November 2011. It is important to note that Turkey appointed Mr. Cemalettin Kani Torun as a Turkish ambassador to Somali on 13 September 2011, who was formerly the director of the Doctors Worldwide Association and working as a medical doctor 
in the UK (Torun, 2015). Importantly, Erdogan particularly preferred to visit Somalia during the month of a holy Ramadan to be able to pay attention of the world to the great droughts not only from the Muslim worlds but also from the other countries (Erdogan, 2011).

Somalia has been facing the greatest humanitarian crisis in the world since 1991 (Elsergany, 2011). During Erdogan's visit, he visited refugee camps and hospitals built by Turkey. Erdogan in his article published the Foreign Policy Magazine explains the main purposes of Turkey's involvement in Somalia. They are as follows: (1) to strengthen historical relations, (2) to alleviate humanitarian crisis, (3) to rebuild the country, (4) to restore peace and security in the country, (5) to attract attention of the greatest drought to the world, and (6) to contribute to peace and security in the region (Erdogan, 2011). The President Erdogan in his article emphasised that "regardless of which culture we come from or where we live, I am confident that our common heritage as human beings will motivate us to ease the suffering of Somalia" (Erdogan, 2011).

Somalia has been the most important pillar of Turkey's Africa policy which was officially launched in 2005. The number of the high level official visits between the two countries has increased significantly after 2011. A friendship group was first established between the Turkish Parliament and the Somali Parliament in 2011 ("Meclis 5 Ulke ile Dostlugu Kesti", 2015). The Somali President Hassan Sheikh Mohamud paid an official visit to Turkey to increase the bilateral relations on 4-7 December 2012 ("Somali Embassy President Hassan Visits Turkey", 2015). The president Hassan Sheikh Mohamud also travelled to Istanbul to join the opening ceremony of the undersea Marmaray railway project on 29 October 2013 (Daly, 2013). The then Somali Prime Minister Abdi Farah Shindon visited Turkey to discuss a wide range of the issues related to Somalia with Gul and Erdogan on 25-30 October 2013 ("Sehit Polisin Adi Somali'de Yasayacak", 2015). The then Deputy Prime Minister Bekir Bozdag came to Somalia to launch operations of the Turkish Airlines (THY) from Istanbul to Mogadishu on 6 March 2012 ("History of Somalia has Changed", 2015). Bozdag also joined the meeting of the council of the Somali ministers on 17 July 2012 and had a meeting with Somalia's former President Sheikh Sharif Ahmed ("Bekir Bozdag Somali'de", 2015).

Turkey organized international conferences on Somali in cooperation with the international organizations in order to strengthen the capacity of state-building and economic development of Somalia. The first Turkey-Somalia Conference was held in Istanbul on 21-23 May 2010 and the Istanbul Declaration was adopted at the conference. 
The UN General-Secretary and the high level representatives of the international organizations took part in this conference ("Ortak Basin Toplantisi”, 2015). Turkey organized a Somali Civil Society Groups meeting in Istanbul on 26 May 2012 and more than 300 representatives of Somali civil society attended in this meeting. The representatives discussed the existing problems surrounding Somalia and the future of Somalia. It was the first time Turkey achieved gathering more than 300 representatives of Somali civil society ("Istanbul'da Somali Nereye Dogru Gidecek?", 2015). The Second Istanbul-Somalia conference was held in Istanbul under the theme: "Preparing Somalia's Future: Goals for 2015" on 31 May - June 2012 ("Istanbul Somali Konferansi", 2015).

The then Turkish Foreign Minister Ahmet Davutoglu actively took part in the Somali conferences held in London on 23 February 2012 and 7 May 2013 ("Disisleri Bakani Davutoglu Londra'da Duzenlenen Somali Konferansina Katildi", 2015). Importantly, the Somali President Hassan Sheikh Mohamud and the Somaliland President Ahmed Mohamed Silanya came to Turkey so as to reinforce the reconciliation process and signed the Ankara Declaration on 13 April 2013 ("Somali ve Somaliland Cumhurbaskanlarinin Imzaladiklari Ankara Bildirisi", 2015). It was the first time the presidents of Somaliland and Somalia came together in Istanbul to boost the unity and solidarity under the leadership of Turkey (“Ankara'da Tarihi Somali Zirvesi”, 2015).

The President Erdogan visited Somali on 25 January 2015. During his visit, he opened the newly-built terminal of Mogadishu airport and a hospital which is one of the largest and most modern hospitals in the region. Both projects were financed and completed by Turkey ("Relations between Turkey and Somalia", 2015). Ali notes that Turkey has become a non-traditional political actor in Somalia. While the traditional actors only focus on their security and material dimensions of their political relations, Turkey has developed a humanitarian approach towards Somalia. This has particularly disturbed the traditional actors'

Inquipy 2016/2 policy towards Somalia and forced them to change their static and security oriented foreign policies in Somalia (Ali, 2011). The report published by the International Crisis Group in 2012 also highlights that the Islamic identity the AK Party politicians hold strongly and the deep Ottoman history in Somalia particularly motivated Turkey to get involved in humanitarian crisis in Somalia (International Crisis Group, 2012). Gullo points out that Turkey's Somalia policy has increased her soft power in world politics. Turkey has redefined her foreign policy objectives during the AK Party government. The concept of "strategic depth" paved the way for establishing a proactive foreign policy in Somalia in particular and in Africa in general. Turkey's active foreign policy 
indicates that Turkey has been shifting her Kemalist/military oriented foreign policy to an independent foreign policy. Furthermore, Turkey had very poor political relations with the African countries until the 2000s but the new Turkey aims to change it and consolidates her global recognition by increasing bilateral relations with the African countries (Gullo, 2012). The growing diplomatic and political relations between Turkey and Somalia have paved the way for facilitating the rebuilding process of Somalia. The growing political and diplomatic relations between Turkey and Somali has indicated that Turkey has been developing a multidimensional foreign policy and changing the static foreign policy discourse of the old Turkey.

\section{THE STATE ACTORS' INVOLVEMENT IN SOMALIA}

There are two actors involving in the rebuilding process of Somalia. These are state actors and non-state actors. Among the state actors, the Turkish International Cooperation and Coordination Agency (TIKA) is one of the most important state actors making efforts so as to rebuild the country. TIKA has implemented a significant number of projects in Somalia ranging from education to health, from infrastructure to agriculture. TIKA provided all the equipments and materials of the Mogadishu Turkish hospital opened in January 2015, which was built by the Turkish Housing Development Administration (TOKI). The hospital is the most modern hospital in East Africa and thousands of people have received free treatment since the opening of the hospital ("Somali Turkiye Egitim ve Arastirma Hastanesi Hizmete Açildi”, 2015). Furthermore, TIKA has been providing financial support and equipments for many hospitals for their rehabilitation in the different regions of Somalia (Kamu Diplomasisi Koordinatorlugu (KDK), 2015). TIKA drilled 19 water wells in Mogadishu in 2012 and 5 water wells in Somaliland. Thousands of people have been access to clean drinking water after opening of the water wells ("Somali'de 400 bin Insan Temiz Icme Suyuna Kavusturuldu", 2015). Importantly, it reconstructed the Mogadishu airport and strengthened the technical infrastructure of the airport in January 2015. Furthermore, TIKA constructed the $24 \mathrm{~km}$ road to connect different cities in Mogadishu in 2014 ("Basbakan Erdogan TİKA'nın 5 Projesinin Açılısını Yaptı”, 2015). It has also constructed the state buildings in Mogadishu and in Somaliland. In addition, TIKA has distributed goats to the villagers to strengthen the animal husbandry in Somalia ("Bekir Bozdag ve Cevdet Yilmaz Somali ve Sudan'i Ziyaret Etti”, 2015). In December 2012, it established an agricultural School in Somalia in cooperation with the IHH (Humanitarian Relief foundation) to strengthen the infrastructure of agriculture in the country. 500 stu- 
dents have graduated from this school to date ("TİKA'nın Destegi ile Somali Tarim Okulu Ziraat Fakultesine Donusturuldu", 2015).

One of the most important soft powers of Turkey is to provide humanitarian aid. In parallel with Turkey's growing economic and political power, Turkey has been increasing humanitarian aid in the world since 2005. While Turkey's official development aid was only 85 million dollars in 2002, it reached 3.3 billion dollars in 2013. According to the report published by Turkey's official aid development agency in 2013, Africa benefited most from Turkey's official development aid with the aid figure of 782 million dollars after the region of the Middle East. Importantly, Somalia is among the first three countries in Africa benefited most from Turkey's official development assistance in the last four years (“Turkiye'nin 2013 y1l Toplam Kalkinma Yardimlari 43 Milyar Dolari Asti", 2015). According to the report published by the Global Humanitarian Assistance, Turkey was the third country in 2014 provided most development aid in the world (Development Initiatives, 2014).

TIKA has been providing assistance to the orphanages, schools, universities and students ("Bekir Bozdag ve Cevdet Yilmaz Somali ve Sudan'i Ziyaret Etti", 2015). TIKA also distributed 100 sewing machines to the women who has suffered during the civil war in the country and provided them a sewing course started in August in 2015 and ended at the end of November 2015 ("TIKKA'dan Somali'ye Istihdam Destegi”, 2015). Importantly, TIKA has been a great deal of attention to restoring the Ottoman era architectures, including the mosques, castles, cisterns, shrines, tombs, archive buildings, ports, and government buildings. During the AK Party administration, restoring the forgotten Ottoman era works has been one of the most important priorities in the new Turkish foreign policy. The AK Party Administration has developed her foreign policy in accordance with the Strategic Depth Doctrine (SDD), which highlights the importance of history and geographical position of Turkey. According to the SDD, Turkey should redefine her history and geographical position.

With the establishment of a new secular state in 1923, Turkey aimed to cut off her historical relations with the Ottoman State as well as the Islamic identity the Turk internalized. At the same time, developing relations with the Western world was the most important foreign policy priority for the secular state but the SDD emphasises that Turkey can only become an active global player if Turkey can redefine her historical power and geographical power. In this regard, Somaliland located on the northern side of Somalia has a special place on the Ottoman history. The place remained a part of the Ottoman State between 1555 
and 1916. Particularly, Somaliland had a strategic importance for the Ottoman. For instance, it was used as a gateway to the Red Sea and the Aden Gulf. Furthermore, the Ottoman used to provide security of the holy places by controlling Somaliland. Therefore, the Ottoman built many constructions in this area including the ports, the administration buildings, hospitals, mosques (Kavas, 2001). TIKA has made an agreement with the Somaliland government to restore all the Ottoman architectures in Somaliland ("Afrika'daki Osmanli Eserleri Ihya Edilecek," Aksam, 2015). Importantly, TIKA not only restores the Ottoman era works in Somalia but also aims to restore the whole Ottoman architectures in East Africa ("Afrika'daki Osmanli Mirasi Koruma Altinda", 2015). For instance, TIKA has been restoring a mosque, the shrine of Al-Najashi ${ }^{1}$ and the tombs of the 15 companions of the Prophet Mohammed (saw) in Ethiopia (TIKA, 2015). Likewise, TIKA has been restoring the three Ottoman mosques in Djibouti ("Cibuti'deki Osmanli İzleri Yenilenecek", 2015).

The Turkish Red Crescent (TRC) is an official humanitarian relief organization of the Republic of Turkey which has been actively taking in part of the rebuilding process of Somalia since 2011. TRC has been implementing a wide range of different humanitarian relief projects in Somalia. For example, it set up a camp named as Jazeera Hayat Camp for 3000 people in Mogadishu in 2012 and providing them food and healthcare. It also built a mobile bakery unit nearby the Jazeera Hayat Camp and is producing breads for the camp residents. Between 2011 and 2014, TRC distributed 30.000 tons of humanitarian aid to Somalis in need. In cooperation with the Qatar Red Crescent, TRC has been cleaning the main streets and the roads in Mogadishu. It has distributed garbage bags and 320 garbage containers to the different places in Mogadishu in cooperation with the Istanbul Metropolitan Municipality (IMM) (Turk Kizilayi, 2015). It has also been implementing the projects of the road rehabilitation and construction with the IMM. The roads between Jazeera-Afgoye $(1 \mathrm{~km})$, Jazeera-Medine $(1,5 \mathrm{~km})$, Makkah Al Mukarramah-Bolhowi $(1 \mathrm{~km})$ have been constructed by TRC and IMM. To rebuild up the city of Mogadishu in a modern view, the TRC has removed debris and ruins in the city and has been establishing the modern facilities and buildings for the Somalis and built many micro-hospitals in the different regions of Somalia to provide free health services to Somalis in need. In 2014, TRC provided the necessary equipments and materials of the General Hospital in Beletweyn in 2014. In 2012, TRC has also initiated a vocational school project in cooperation with the

$1 \quad$ He was the Habeshi king and accepted the Muslims who migrated from Mecca to Habeshistan due to the cruelty. Therefore, the king Al-Najashi has a significant place in the Islamic history. 
Ministry of Education (Turk Kizilayi, 2015).

Disaster and Emergency Management Presidency (AFAD) is providing significant humanitarian relief to Somalis in need and is working under the patronage of the Prime Ministry Office. 50 tons of humanitarian relief supplies were sent to Somalia with 21 planes and 11 ships between 2011 and 2015. AFAD has been implementing a wide range of different humanitarian relief projects. It has completed the Drinking Water Pipeline Project, the Water Wells Drilling Projects, the construction of the 200 bed hospital, the construction and the rehabilitation of the roads and the streets. AFAD also provided medical equipments and materials to the different hospitals in Somalia, established the field hospitals, and donated 600 computers to various schools. It is currently conducting the projects on the building of a school for training nurses, and the construction of a mosque. AFAD allocated 139 million Turkish Lira (47 million dollars) for the implementation of the above mentioned humanitarian aid projects in Somalia (AFAD, 2013).

Turkey provides scholarship for the Somali students. The different state institutions in a coordination including the Ministry of Education, the Directorate for Religious Affairs (Diyanet), TIKA, and the Presidency for Turks Abroad and Related Communities (YTB) has brought the Somali students to Turkey to receive education at the different levels. More than 500 Somali students are studying at the Turkish universities ("500 Somalili Turkiye'de Okuyacak", 2015). The Ministry of Health has sent 265 health personnel in Somalia. Thousands of patients have been examined and operated by the Turkish doctors in Somalia (Ministry of Health, 2012).

It can be said that the state institutions have played a significant role on the development of the new foreign policy discourse. Particularly, TIKA is one of the most strategic state instruments of the new foreign policy. While there were no TIKA offices in Africa until 2002, the AK Party government has opened 11 TIKA offices in the different country in Africa. TIKA has involved in a wide range of humanitarian relief activities and expanded and deepened Turkey's Africa policy. More importantly, the restoration of the Ottoman era architectures by TIKA is one of the most important examples showing that the traditional parameters of the Turkish foreign policy have been changing.

\section{GROWING ECONOMIC RELATIONS WITH SOMALIA}

Growing diplomatic relations between Turkey and Somali pave the way for increasing economic and trade relations. Turkey has been developing her economic and trade relations with Somalia and diversifying her foreign policy. Turkish Airlines (THY) began to operate 
direct flights in Somalia in September 2013. The inauguration of international flights of the THY was very important for the economic revival of Somalia because Somalia remained a closed country in the world over the last two decades. The THY became the first international commercial airlines which started long-distance flights since the 1990s and opened Somalia to the world. Importantly, the THY flies to Mogadishu through Sudan every day. With the operation of the THY, Turkish business communities began to engage in the business activities in Somalia more easily (“3. Havalimani Dunyanin Tarihini Degistirecek”, 2015).

Turkish companies have begun to operate the strategic trade entities in Somali. For instance, the Turkish company Albayrak has started to operate the largest international airport in the country since 2013. Due to the long-standing civil war in the country, the international airport of Somalia Aden Adde International Airport was largely destroyed and used to provide very limited service for the citizens until 2015. The Turkish company signed an agreement with the Somali government for the operation, modernization and the construction of the new buildings at the airport in 2013. According to the agreement, the project will cost $\$ 10$ million and the company will operate the airport for 20 years. Furthermore, the company will operate the airport with the model of build-operate-transfer (BOT). The new airport was opened in 2015. While the plane capacity of the airport was only 15 before 2015 , it will be increasing to 60 . Likewise, the passenger capacity of the airport will be increasing from 60 to 5000 . According to agreement, if needed, the same Turkish company will build up another airport in Mogadishu (“Somali'ye Turk Firma Havalimani Yapacak", 2015).

The Turkish firm (PGM) signed an agreement with the Ministry of Industry and Commence in May 2015. According to the agreement, the Turkish firm will inspect the quality of imports and exports products and implement quality assurance standard. Since the 1991s, there have been no regulations on the market products in the country ("Products in Somalia to be Inspected As Government Contracts Turkish Firm", 2015). The Turkish company Albayrak has been operating the largest sea port of Mogadishu since 2014. According to the agreement signed between the company and the government in September 2014, the government will receive 55 percent of the revenues while the company will get the 45 percent of the incomes for using it for the modernization of the sea port. The Turkish company will run the seaport for a 20year period ("Turkish Company Transfers \$1.58200 to Somali Government as Port Revenue of a Month", 2015). The company has allocated $\$ 80$ million for the modernization of the seaport ("Somali Hands over Mogadishu Seaport to Turkish Company", 2015). 
The first Somalia-Turkey Business Forum was organized by the Turkish and Somalia businessmen in Somalia on 7 April 2012. The forum was a historic moment for Somalia because since the 1990s there have not been organized any business forum with any foreign country due to the brutal civil war in the country ("Somali'de 20 yil sonra Is Forumu", 2015). On 6 December 2012, the Somali President Hassan Sheikh Mohamud and his delegation with the then-minister of development Zafer Caglayan joined the Turkey-Somalia Trade and Investment Forum in Istanbul. During the conference, the President Hassan Sheikh Mohamud underlined that there were many business opportunities for Turkish investors and businessmen in Somalia, particularly in the fields of fishing and fish processing industry, energy, construction and building materials and furniture sector. The President invited the Turkish investors to invest in these areas in Somalia. On 21-26 May 2013, Turkey-Somalia Business Forum was organized by the Somalia Council ("Somali-Turkish Business Forum", 2015). It is important to emphasise that organizing bilateral trade and investment forums are significantly important to strengthen economic relations. Since the visit of the President Recep Tayyip Erdogan in August 2011, Turkey has actively increased its presence in Somalia in the fields of trade and investment.

Since 2011, Turkey's economic relations with Somalia has begun to change significantly. Turkey's total trade with Somalia in 2001 was only 516 thousands US dollars. Before the AK Party came to power in 2012, there was a coaliton government in Turkey which destablised economic and political stability. The weak coalition Turkish governments did not have any political and economic relationship with Somalia in 2001 due to the heavy internal challenges in the country. With the AK Party came to power in 2012, the nature of economic relations between Turkey and Somalia has changed. While Turkey's trade relations with Somalia was 6 million dollars in 2010, it reached to 42 million dollars in 2011. It peaked to 63 million dollars in 2014.

Inquiry 2016/2

Developing relations with the West was the most important purpose for the secular governments in Turkey. However, this perception has changed during the AK Party government. The ruling party has diversified her foreign policy and included new aspects of the foreign policy such as economics, security, and humanitarian aid. Economic relations have been increasing between the two countries. Turkey's involvement in Somalia has opened new economic opportunities for the Turkish business environment. While the traditional actors ignore development aid in the country and only focus on their own self-interest or economic dimension, Turkey has been dealing with different aspects of foreign policy, including security, economics, peace-building initiatives, edu- 
cation, health care, and humanitarian relief activities. In other words, Turkey has been implementing a multi-track diplomacy in the country while the traditional actors only concentrate on single-track diplomacy.

Table 1: Turkey's Trade with Somalia (2001-2014) (1000 US Dollars)

\begin{tabular}{|l|l|l|l|}
\hline year & export & import & total \\
\hline 2001 & 198 & 318 & 516 \\
\hline 2005 & 2,207 & 839 & 3,562 \\
\hline 2010 & 4,810 & 1,361 & 6,171 \\
\hline 2011 & 39,548 & 2,465 & 42,013 \\
\hline 2012 & 43,788 & 1,165 & 44,953 \\
\hline 2013 & 58,315 & 1,052 & 59,397 \\
\hline 2014 & 62,119 & 1,523 & 63,642 \\
\hline
\end{tabular}

\section{EVOLVING SECURITY RELATIONS WITH SOMALIA}

Maintaining peace and security is fundamental for economic and social development. It can be said that without sustaining peace and security in Somalia, Turkey's contribution to Somalia in the different fields does not make sense. In this regard, Turkey has also involved in the maintenance of peace and security. Due to the civil war in the country, the police mission and the Somalia Armed forces (SAF) were destroyed and these functions have not been re-established since 1990s. As a result of the lack of a strong national army and the police mission, there has been a security vacuum in the country for a long time. To re-establish security in the country, Somali requested from Turkey to strengthen the police mission and the national armed force in 2010. Turkey signed her first military training pact with Somalia on 22 May 2010 in Ankara ("Turkey, Somali Sign Military Training Pact", 2015). Turkey allocated 20 million Turkish Lira for the modernization and the rebuilding up of the Somali police mission and the armed forces ("TSK Somali Askerini Egitecek", 2015).

Turkey has sent her military instructors to Somalia to expand and widen the military cooperation with Somalia in different dates. According to the military agreement, Turkish Army will provide the military training for the Somali soldiers and the Somali police officers in cooperation with General Directorate of Security of Turkey. Furthermore, Turkey will establish a sergeant school and Air, Sea and Infantry schools as well. More than 500 police officers have received education in Turkey. 
In September 2013, 110 Somali soldiers began to receive their military education in Ankara and completed their education in July 2014 ("TSK'da Egitim Alan Somalili Askerler Mezun Oldu", 2015). On 13 April 2012 ("Military Pact between Turkey and Somali", 2015) and 28 February 2014, Turkey re-signed military agreements with Somalia to institutionalize and reinforce her security relations. According to the agreements, Turkey will establish military bases in the country and boost cooperation with Somalia in the areas of peace support, humanitarian relief, military logistic and counter-piracy ("Somali and Turkey Sign Military Agreement", 2015). The Turkish Navy forces have been operating off the coast of Somalia to counter piracy and combat the armed robbery since 2009 ("Meclis Somali Tezkeresini Uzatti", 2015). Turkey has also providing financial support for the African Union Mission in Somalia (AMISOM) since 2009. To date, Turkey has provided two million US dollars to strengthen the AMISOM ("Turkiye'den Somali'ye 1 Milyon Dolar Destek", 2015). Involving peace and security has been an important strategy of the new Turkish foreign policy. According to the ruling party, there is no economic and social development without security. In this regard, Turkey has contributed to peace and security. For instance, it has been building military schools in Somalia and educating the Somali army and police officers. Importantly, Turkey does not pursue a security-oriented foreign policy towards Somalia. Security policy of Turkey in Somalia has been supported by different dimension of the new Turkish foreign policy discourse, including humanitarian aid, education, diplomacy, economic relations and the renovation of the destroyed infrastructure.

\section{CONCLUSION}

With an economic and political stability which Turkey has been maintaining since 2002, Turkey has been playing a more active role in the world politics. For instance, the coalition government in Turkey in 1998 failed to implement the African strategy which adopted by the government in 1998. The reason was that Turkey was weak politically and economically in the 1998. With the AK Party, Turkey has become a growing economic power in the world. She is ranked as the $6^{\text {th }}$ largest economic power in Europe and $16^{\text {th }}$ in the world. Developing economic relations with different regions and continents and strengthening a multidimensional foreign policy discourse have become one of the most important objectives of the new foreign policy. It can be said that the new foreign policy discourse not only focuses on security and politics but also economic opportunities. Somalia has been the most important country in Africa to deepen and strengthen Turkish foreign policy to- 
wards Africa. Turkish foreign policy towards Somalia not only helps to increase regional power of Turkey but also enhances her international power in world politics. Continuity is essential for the success in foreign policy. The future of Turkish foreign policy in Africa depends on political and economic stability in Turkey. Turkey's growing relations with Somalia reflect the Islamic identity which the majority of the country holds and the transformation on Turkish domestic policy. The Somali case is showing that the Islamic identity of the ruling party is the most important dynamics for rapprochement between Somalia and Turkey.

The military and the bureaucracy are not the main powers on the making of Turkish foreign policy anymore. The new actors have joined the foreign policy making process actively. For instance, NGOs, universities, think tanks, the public and business sectors have actively taken part in it. In this regard, the Turkish NGOs have significantly contributed to developing the new foreign policy discourse. The state actors have been also working with the Turkish NGOs in a wide field of humanitarian areas in Africa. It is important to note that the Turkish NGOs providing humanitarian relief in Somali have strong Islamic identities which force the Islamic society in Turkey to do something for the sake of the humanity regardless of race, nation, and religion. This also demonstrates that the nature of the secular foreign policy has been changing in Turkey and the Islamic values have been a significant part of the new foreign policy discourse.

\section{REFERENCES}

AFAD (2013). Idare Faaliyet Raporu 2013, pp. 1-17, 7 August 2015,

https://www.afad.gov.tr/Dokuman/TR/71-2014052014474-afadfaaliyetraporu2013. pdf

“Afrika'daki Osmanli Mirasi Koruma Altinda”, Yenisafak, 24 July 2015, http:// www.yenisafak.com/aktuel/afrikadaki-osmanli-mirasi-koruma-altinda-384385 Akpinar, P. (2013). Turkey's Peacebuilding in Somalia: The Limits of Humanitarian Diplomacy. Turkish Studies, Vol. 14, No 4, pg. 740.

Ali, A. (2011). Turkey's Foray into Africa: A New Humanitarian Power? Insight Turkey, Vol. 13, No. 4, pg. 70 .

“Ankara'da Tarihi Somali Zirvesi”, Ministry of Foreign Affairs of Turkey, 16 June 2015, http://www. mfa.gov.tr/ankara-da-tarihi-somali-zirvesi-somali-ve-somaliland-cumhurbaskanlari-ankara-dabiraraya-geldi.tr.mfa

“Basbakan Erdogan TİKA’nin 5 Projesinin Açilisini Yapti,” Haber7, 9 July 2015, http://www.haber7.com/ guncel/haber/1159400-basbakan-erdogan-tikanin-5-projesinin-acilisini-yapti

“Basbakan Somali'de,” Sabah, 4 March 2015, http://www.sabah.com.tr/dunya/2011/08/19/basbakan-somalide

“Bekir Bozdag Somali'de”, İHA, 1 June 2015, http://www.iha.com.tr/haber-bekir-bozdag-somalide-235332/ Bingol, O. (2013). Turkey's Role in Somali's Peace and Development Process. Akademik Bakis, Vol. 7, No 
Dr. Abdurrahim Siradag

13, pg. 100.

“Cibuti'deki Osmanlı İzleri Yenilenecek", TİKA, 29 July 2015, http://www.tika.gov.tr/tr/haber/ cibuti_ deki_osmanli_izleri_yenilenecek-14830

Daly, J. C. K. (2013). Turkey’s Undersea Marmaray Railway Tunnel Unites Europe, Asia, 26 May 2015, http://www.jamestown.org/single/?tx_ttnews[tt_news]=41551\&no_cache=1\#.VfgHZn1EyM8

“Disisleri Bakanı Davutoglu Londra'da Duzenlenen Somali Konferansina Katildi, 12 June 2015”, Ministry of Foreign Affairs of Turkey, http://www.mfa.gov.tr/disisleri-bakani-davutoglu-londra_da-duzenlenen-somali-konferansi_na-katildi.tr.mfa

Elsergany, R. (2011). Erdogan Visits Famine-Hit Somalia, 18 May 2015, http://islamstory.com/fr/ node $/ 31273$

Erdogan, R.T. (2011). The Tears of Somalia, 18 May 2015, http://foreignpolicy.com/2011/10/10/the-tearsof-somalia/

Erol, M.S. and Altin, A. S. (2012). Turk Dis Politikasinda Afrika: Osmanli Mirasi Uzerine Ortak Gelecek (I), 15 April 2015, http://www.usgam.com/tr/index.php?1=844\&cid=646\&konu=0\&bolge=12

Gullo, M. T. (2012). Turkey's Somalia Adventure: The Quest for Soft Power and Regional Recognition. Centre for Policy Analysis and Research on Turkey, London: ResearchTurkey, pp. 6-9.

"History of Somalia has changed", Dunya, 27 May 2015, http://www.dunya.com/mobi/bozdag-history-of-somalia-has-changed-147858h.htm

“3. Havalimani Dunyanin Tarihini Degistirecek, Aksam, 21 September 2015, http://www.aksam.com.tr/ekonomi/3-havalimani-dunyanin-tarihini-degistirecek/ haber-410602

International Crisis Group (2012). Assessing Turkey's role in Somalia. Africa Briefing No 92, pg. 3-6.

“Istanbul'da Somali Nereye Dogru Gidecek?”, Timeturk, 7 June 2015, http://www.timeturk.com/tr/2012/05/31/somali-nereye-dogru-gidiyor.html

"II. Istanbul Somali Konferansi", Ministry of Foreign Affairs of Turkey, 12 June 2015, http://www.mfa. gov.tr/2-istanbul-somali-konferansi.tr.mfa

Kamu Diplomasisi Koordinatorlugu (KDK), Bekir Bozdag ve Cevdet Yilmaz Somali ve Sudan'i Ziyaret Etti, 28 June 2015, http://www.kdk.gov.tr/haber/bekir-bozdag-ve-cevdet-yilmaz-somali-vesudani-ziyaret-etti/226

Kavas, A. (2001). Dogu Afrika Sahilinde Osmanli Hakimiyeti: Kuzey Somali'de Zeyla

Iskelesinin Konumu (1265-1334/1849-1916). Islam Arastirmalari Dergisi, Issue 5,pp. 112-116.

$2016 / 2$ KDK, Bekir Bozdag ve Cevdet Yilmaz Somali ve Sudan'i Ziyaret Etti, 28 June 2015, http://www.kdk.gov.tr/haber/bekir-bozdag-ve-cevdet-yilmaz-somali-ve-sudani-ziyaret-etti/226

KDK, Bekir Bozdag ve Cevdet Yilmaz Somali ve Sudan'i Ziyaret Etti, 21 July 2015, http://www.kdk.gov.tr/haber/bekir-bozdag-ve-cevdet-yilmaz-somali-ve-sudani-ziyaret-etti/226

"Meclis Somali Tezkeresini Uzatti," Haberevet, 29 October 2015, http://www.haberevet.com/guncel/meclis-somali-tezkeresini-uzatti-h671575.html “Meclis 5 Ulke ile Dostlugu Kesti," Radikal, 21 May 2015, http://www.radikal.com. 
tr/politika/meclis_5_ulkeyle_dostluku_kesti-1068046.

"Military Pact between Turkey and Somali," Resmi Gazete, 28 October 2015, http:// www.resmigazete.gov.tr/eskiler/2012/10/20121010-4-1.pdf

Ministry of Health (2012). Faaliyet Raporu, pg. 112, 21 August 2015, http://www.saglik.gov.tr/TR/dosya/1-82968/h/faaliyetraporu2012.pdf

“Ortak Basin Toplantisi”, Ministry of Foreign Affairs of Turkey, 5 June 2015, http:// www.mfa.gov.tr/sayin-bakanimizin-istanbul-somali-konferansi-sonrasi-bmgenel-sekreteri-ile-yaptigi-ortak-basin-toplantisi_-22-mayis-2010.tr.mfa

"Products in Somalia to be Inspected As Government Contracts Turkish Firm", Somali Current, 29 September 2015, http://www.somalicurrent.com/2015/05/24/products-in-somalia-to-be-inspected-as-govt-contracts-turkish-firm/

"Relations between Turkey and Somalia", Ministry of Foreign Affairs of Turkey, 16 June 2015, http:// www.mfa.gov.tr/relations-between-turkey-and-somalia.en.mfa

Sanei, E. (2013). Somali-Turkish Relations: Opportunities and Challenges, 12 March 2015, http://www.internationalpolicydigest.org/2013/01/22/somali-turkish-relations-opportunities-and-challenges/

“Sehit Polisin Adi Somali'de Yasayacak," Haber7, 26 May 2015, http://www.haber7.com/guncel/haber/1079379-sehit-polisin-adi-somalide-yasayacak

Siradag, A. (2013). The Making of the New Turkish Foreign and Security Policy towards Africa: The Rationale, Roots and Dynamics. Africa Insights, Vol., 43, No 1, pg. 20.

“Somali and Turkey Sign Military Agreement,” Keydmedia, 28 October 2015, http://www.keydmedia.net/ en/news/article/somalia_and_turkey_sign_military_agreement

Somali Embassy, President Hassan Visits Turkey, 25 May 2015, http://www.somaliembassytr.org/president-hassan-visits-turkey/4571715225

"Somali Hands over Mogadishu Seaport to Turkish Company," Diplomat, 7 October

2015, http:/diplomat.so/2014/09/21/somalia-hands-over-mogadishu-seaport-to-turkish-company/

“Somali-Turkish Business Forum”, Somali Council, 17 October 2015, http://www.thesomalicouncil.org/ programs/turkey/Turkish.pdf

"Somali Turkiye Egitim ve Arastırma Hastanesi Hizmete Açıldı", TİKA, 21 June 2015, http://www.tika. gov.tr/tr/haber/somali_turkiye_egitim_ve_arastirma_hastanesi_cumhurbaskani_recep_tayyip_erdogan_tarafindan_hizmete_acildi-14817

“Somali’ye Turk Firma Havalimani Yapacak”, Aksam, 24 September 2015, http://www.aksam.com.tr/ekonomi/somaliye-turk-firma-havalimani-yapacak-162839h/haber-162839

“Somali ve Somaliland Cumhurbaskanlarinin Imzaladiklari Ankara Bildirisi”, Ministry

of Foreign Affairs of Turkey, 15 June 2015, http://www.mfa.gov.tr/somali-ve-somaliland-cumhurbaskanlarinin-imzaladiklari-ankara-bildirisi_-13-nisan-2013_-ankara.tr.mfa

"Somali'de 400 bin Insan Temiz Içme Suyuna Kavusturuldu”, TİKA, 2 July 2015, http://www.tika.gov.tr/tr/haber/somali_de_400_bin_insan_temiz_icme_suyuna_kavusturuldu-16331 
Dr. Abdurrahim Siradag

“Somali' de 20 yil sonar Is Forumu”, Timeturk, 15 October 2015, http://www.timeturk. $\mathrm{com} / \mathrm{tr} / 2012 / 04 / 07 /$ somali-de-20-yil-sonra-is-forumu.html

“500 Somalili Turkiye'de Okuyacak “, AK Parti, 18 August 2015, http://www.akparti. org.tr/site/haberler/500-somalili-ogrenci-turkiyede-okuyacak/12360\#1

The Official Website of the Government of Somalia, The UN Failures, 24 April 2015, http://www.somaligov.net/TheUNFailures.html

“TİKA'dan Somali'ye Istihdam Destegi”, TRT, 22 July 2015, http://www.trtturk.com/haber/tikadan-somaliye-istihdam-destegi-144018. html

“TİKA'nın Destegi ile Somali Tarim Okulu Ziraat Fakultesine Donusturuldu”, TİKA, 14 July 2015, http://www.tika.gov.tr/tr/haber/tikanin_destegiyle_somali_ tarim_okulu_ziraat_fakultesine_donusturuldu-8072

Torun, K., 28 May 2015, http://www.kanitorun.com.tr/

“TSK' da Egitim Alan Somalili Askerler Mezun Oldu," Ensonhaber, 27 October 2015, http://www.ensonhaber.com/tskda-egitim-alan-somalili-askerler-mezunoldu-2014-07-15.html

“TSK Somali Askerini Egitecek”, Yenisafak,” 29 October 2015, http://www.yenisafak.com/gundem/tsk-somali-askerini-egitecek-495667

“Turkey, Somali Sign Military Training Pact”, Trend, 21 October 2015, http://en.trend.az/world/turkey/1692644.html

"Turkis Company Transfers $\$ 1.58200$ to Somali Government as Port Revenue of a

Month”, Raxanreeb, 3 October 2015, http://www.raxanreeb.com/2014/11/somaliaturkish-company-transfers-1-582000-to-somali-government-as-port-revenueof-a-month-photos/

“Turkiye'den Somali'ye 1 Milyon Dolar Destek," Yeniasir, 30 October 2015 http:// www.yeniasir.com.tr/politika/2012/06/02/turkiyeden-somaliye-1-milyondolar-destek

“Turkiye'nin 2013 yili Toplam Kalkinma Yardimlari 43 Milyar Dolari Asti”, KDK, 17 July 2015, http://kdk.gov.tr/haber/turkiyenin-2013-yili-toplam-kalkinmayardimlari-43-milyar-dolari-asti/500

TurkK1zılayı (2015). Somalia, pp. 3-16, 29 July 2015, http://riga.emb.mfa.gov.tr/images/localCache/1/3211cb2a-2d50-4984-b0c07a2d47437867.pdf

Inquiry Ugur, H. (2005). Afrika Kitasinda Osmanli Varligi, 1 April 2015, http://www.anlayis. $2016 / 2$ net $/$ makaleGoster.aspx?dergiid $=22 \&$ makaleid $=4142$ 